\title{
Examining the Internet Quota Subsidy Policy in Indonesia
}

\author{
Sajida \\ Departement of Public Policy and Management, Faculty of Social and Political Sciences, Universitas Gadjah \\ Mada (email : halosajida@gmail.com) \\ Ranjani \\ Departement of Public Policy and Management, Faculty of Social and Political Sciences, Universitas Gadjah \\ Mada (email : ranjanirara98@gmail.com)
}

\begin{abstract}
The pandemic in Indonesia requires a moving from offline learning to online learning to reduce the spread of COVID-19. However, that practice facing some problem like the increment households spending for internet access, and inequality access technology. As a form of accountability and responsibility for these problems, the Indonesian government by the Ministry of Education and Culture made a policy of subsidizing internet quota for all teachers, students, and lecturers for four months. This subsidy was made to support distance learning during the pandemic. This article aims to examine the implementation of the internet quota subsidy policy. The literature review method is carried out by looking at previous research related to aid/subsidies policies during the crisis, policy implementation, and internet quota subsidy in Indonesia. The sources were collected from articles, reports, and mass media. The results show that looking at the output and the initiation, this policy has been running quite well as part of the government's agility response. However, this policy was not effective enough to support distance learning during the pandemic as a whole in Indonesia. Several findings indicate there is inequality of internet access in some outlying areas where the benefits of this policy cannot be felt.
\end{abstract}

\section{Keywords:}

internet quota subsidy; online learning; policy implementation

\section{Introduction}

The COVID-19 pandemic has forced various changes in human activities in various sectors, including education. More than 100 countries have implemented the closure of education facilities nationally (Nicola et al, 2020) including Australia, India, Egypt, Germany, Hong Kong, Italy, Nigeria which closed educational institutions and other public sectors that are at high risk of becoming areas of the spread of COVID-19 (Crawford et al, 2020). UNESCO estimates that around 900 million students are affected by the temporary closure of these educational institutions (Nicola et al, 2020).This is a quick response from the government to reduce the spread of the virus through physical distancing. Because, the characteristics of COVID-19 have an incubation period of about 5 days, so cases in each school can tend to 
increase twofold if the school is fully opened (Gandolfi, 2020). Distance learning or online learning is the only alternative chosen by the majority of countries in various parts of the world. Although many countries have experienced natural disasters and man-made disasters, distance learning has not been used as a solution to the crisis as implemented after the corona virus crisis. Crisis distance education (CDE), usually used in the midst of a crisis, makes it impossible to apply in the midst of a pandemic (Lily et al, 2020). This online learning takes advantage of various applications with the help of internet access to be able to face to face virtually, like learning in class. For example, an electronic application called ZOOM which facilitates the implementation of live teaching and learning activities, virtual conferences, virtual seminars, interaction using video, and in-person meetings (Dhawan, 2020). Besides, an example of the implementation of online learning in South African is the government's policy through the Department of Basic Education (DBE) to introduce online student support programs such as COVID-19 TV and radio curriculum support programs for students. (Mbunge, 2020).

However, the process of switching from traditional or mixed learning methods to virtual and online learning strategies will not be completed overnight and there are many challenges, such as the lack of a 'home office' infrastructure or student facilities (Crawford, 2020). in Turkey, Most of the teaching staff who work in public/tertiary schools stated that their students had problems with an internet connection and network capacity (Korkmaz et al, 2020). Even in western countries such as Brazil, the USA, Mexico, the implementation of online learning must also face serious problems regarding the inequality of opportunities for access to education or online learning (Chéné, 2020)

In response to various problems such as these, several countries have taken quick response steps through various aid policies. Since March 27, Malaysia issued a financial support policy in the form of the People's PRIHATIN Economic Stimulus Package (PRIHATIN Package). Contains the payment of the National Higher Education Fund (PTPTN) loan which will be postponed until 30 September 2020; Free internet from all telecommunication companies from 1 April 2020 until the end of MCO for all Malaysian citizens; RM 200 describes one-time financing for higher education students. (Md Shah et al, 2020). Almost like Malaysia, in the US, on March 27, the virus subsidy package worth $\$ 2$ trillion from the CARES Act, as support for the economy to survive these times. details include 
$\$ 500$ for each child under 17 years of age, and student enrollment fees will be postponed until September 30 without penalty (Nicola et al, 2020). Meanwhile, in Turkey, the Ministry of Education (MONE) is working with Turkey's leading GSM operator to support student access to the EBA online portal. The operator facilitates internet access up to 8 GB for free for students. This free internet access can be used by students to count in online courses and other educational activities on the EBA website (ÖZER, 2020).

Interestingly in the context of Indonesia, the pandemic that has infected since March 2020 has an impact on changing the learning system from face-to-face to distance learning (PJJ) as another term for online learning or distance learning. As regulated in the Circular of the Minister of Education and Culture Number 2 of 2020 and Number 3 of 2020 concerning Online Learning and Working from Home in the Context of Preventing the Spread of Corona 19 Virus Disease (COVID-19) online teaching and learning activities have been carried out since March 9. 2020. However, reality shows that The implementation of online learning also has problems that are not much different from the other countries mentioned earlier. Some of the problems that become obstacles to this are Not all parents, especially those from lowincome families, have mobile phones or laptops to facilitate their children's online learning, and the Internet signal is also very poor, especially in the suburbs. Some parents have low Internet literacy, which is a problem. Large scale social improvement programs to increase the number of layoffs, this raises economic problems. Especially for students whose parents are victims of layoffs, a decrease in income means a decrease in the ability to meet the need for internet services. In fact, some students don't have the cell phones or laptops they need to study with teachers in virtual classrooms. (Rasmitadila et al, 2020). Then, the government responded to this crucial issue through the internet quota subsidy policy. This policy aims to support distance learning during the pandemic. This policy is one of the government's responsive policy innovations to provide education support. This is why in this article we will describe the implementation of policies that are "considered" to be the most concrete solutions by governments in supporting online learning.

\section{Methods}

This study focuses on (a) The implementation of the quota subsidy policy in Indonesia according to various relevant theoretical references (b) The advantages and disadvantages of 
implementing the internet quota subsidy policy according to various relevant references. By following the focus, a literature study research method was used. According to Creswell (2014: 40), literature review is a written summary that comes from articles in journals, books and other documents that describe previous and current theories and information, discussion of literature is the topic and document needed. Therefore, research that discusses internet quota subsidy policies in Indonesia is also based on various disciplines, and we focus on policy implementation, policy processes, policy design, and public administration studies. The main source used in this research comes from Google Scholar, UGM Digital Library that provides Journal Articles from Sage Publications, Science Direct, Emerald, and et cetera. The discovery of articles in depth using keywords or long search words such as subsidy in crisis, internet subsidy, online learning, policy implementation, distance learning, aid in education, and et cetera. Then, we filter article searches by year from 2010 to this year, 2020, and there are around 1,140,000 results in keywords, online learning. However, in this study, we only focused on the implementation of online learning which led to an internet quota subsidy policy, specifically in Indonesia. The writer analyzes and chooses the title independently to the substance that matches the subject matter of this paper. The results of the acquisition and selection are then analyzed using descriptive analysis method, by describing the facts which are then translated into analysis, not just describing it, but also providing adequate understanding and explanation.

\section{Results and Discussion}

\section{Implementation of The Internet Quota Subsidy Policy}

The COVID-19 pandemic that has occurred since 2 March 2020 has also resulted in changes to the learning system based on various provisions from the Circular of the Minister of Education and Culture Number 2 of 2020 and Number 3 of 2020 concerning online learning and working from home as an effort to prevent the spread of the Corona Virus Disease (COVID) -19) which was originally a face-to-face meeting now a distance learning (PJJ) as

another term for online learning or distance learning. Empirical facts show that online learning and teaching activities still reap many things related to the preparation of human resources, unclear local government development, lack of appropriate courses, and limited facilities and infrastructure, especially related to technical support and internet networks. 
(Fieka, 2020). This condition has an impact on decreasing the opportunities for teachers and students to have the best experience in the teaching and learning process. Online learning also creates new problems, especially for students with poor internet infrastructure, resulting in disparity in internet access due to differences in economic abilities and limitations in digital use for teachers and students. This problem has initiated the formulation of an internet quota subsidy policy for students and teachers, and at the time of writing, the policy is in the implementation stage.

Discussing policy implementation will often look at how this policy process focuses on the implementation or realization of regulations that have been compiled at the formulation stage. Various approaches to policy implementation have been expressed by both traditional scholars who separate rigidly between the top-down approach (Pressman and Wildavsky (1973), Van Meter and Van Horn (1975), Bardach (1977), Sabatier and Mazmanian $(1979,1980)$.$) , Mazmanian and Sabatier (1983)) and the bottom-up approach (Lipsky (1971,$ 1980) Elmore (1980) Hjern and Porter (1981) Hjern (1982) Hjern and Hull (1982)), as well as academics who are now developing the approach collaborative policies (Koontz et al (2014), Homsy et al (2019), Ansell et al (2019), Taylor (2018)). However, in this implementation analysis, we see how this quota subsidy subsidy policy tends to be top-down. This is because this policy is given from the center and is directly supervised by the The Ministry of Education and Culture through a decree from the Secretary General Number 14 of 2020 concerning Technical Guidelines for Internet Data Quota Subsidy in 2020. Furthermore, for analysis in the implementation of this internet quota subsidy policy, We use an integrated implementation approach model by Winter which consists of three groups of variables: public policy formulation, public policy implementation process, and public policy implementation results (Vancoppenolle et al, 2015). 
Picture 1.

Integrated Implementation Model by Winter

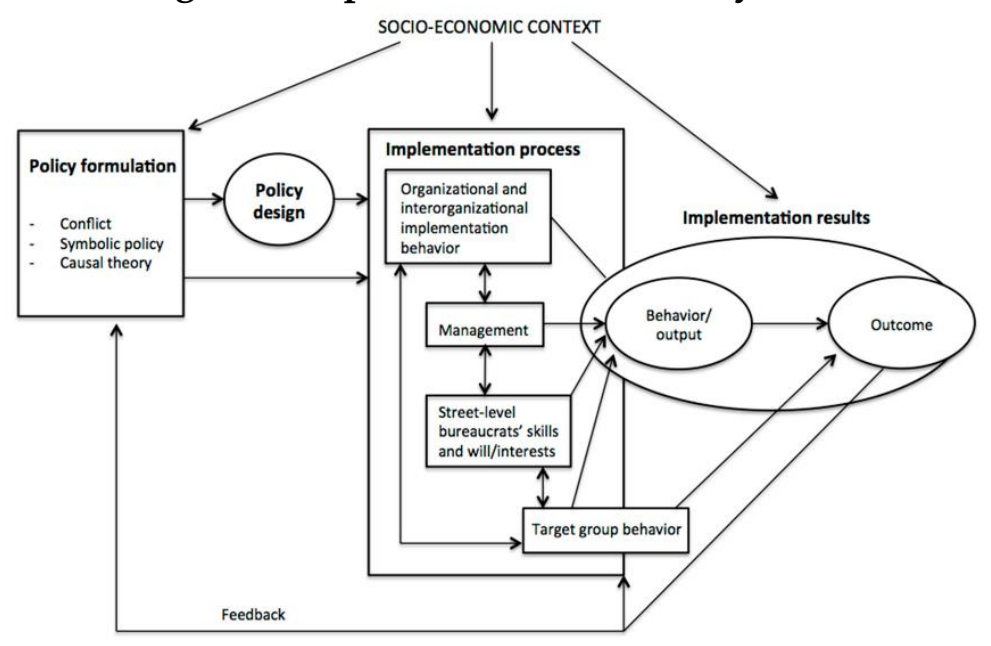

Source : Vancoppenolle et al (2015)

Where then Vancoppenolle et al (2015) simplify the focus of the analysis of policy implementation on several important points from the concepts offered by Winter. Where then he separates three independent variables, namely the policy design, the policy implementation structure, the behavior of the target group that will affect the program results of a policy (Vancoppenolle et al, 2015). Furthermore, here will describe the details of each of these aspects.

\section{Policy Design}

Public policy consists of policy design, which aims to convey the key elements, connections and basic logic of achieving policy goals (Carter et al, 2015). Policy definition as "the content of public policy found in policies, practices through which policies, and subsequent policies related to these practices" (Pierce et al, 2014); This design has a feedforward effect ((Pierce et al., 2014, Schneider \& Sidney, 2009) in (Wolf, 2019). Policy designs are made to develop effective policies, so it is necessary to understand if and how to formulate and implement effective policies (Capano, Howlett, 2019).

The policy design for the internet quota subsidy is stated in the Secretary General's Regulation Number 14 of 2020 concerning the Technical Guidelines for Internet Data Quota Subsidy for 2020. This policy is formulated and is the responsibility of the minister of education and culture. Some of the basic things about this subsidy are;

1. Purpose : Internet data quota subsidy are designed supporting the implementation of studying at home during the Corona Virus Diseases 2019 (COVID-19) pandemic. 
2. Subsidy : Subsidy is provided by the Center for Data and Information Technology through mobile operators.

3. Form of subsidy: in the form of internet data quota, namely general quota and study quota. General Quota, which is the quota that can be used to access all pages and applications. Meanwhile, the Study Quota, which is a quota that can only be used to access learning pages and applications, is listed on http://kuotabelajar.kemdikbud.go.id/.

Table 1.

Details of Internet Quota Subsidies

\begin{tabular}{|c|c|c|c|c|c|}
\hline \multirow[t]{2}{*}{ Number } & \multirow[t]{2}{*}{ Detail } & \multirow[t]{2}{*}{ Volume } & \multicolumn{2}{|c|}{ Volume Distribution } & \multirow{2}{*}{$\begin{array}{l}\text { Subsidy } \\
\text { Duration }\end{array}$} \\
\hline & & & Kuota Umum & Kuota Belajar & \\
\hline 1 & $\begin{array}{c}\text { Internet Data Quota Package for } \\
\text { Early Childhood Education } \\
\text { (PAUD) Students }\end{array}$ & $\begin{array}{l}20 \mathrm{~GB} / \\
\text { month }\end{array}$ & $5 \mathrm{~GB} /$ month & $15 \mathrm{~GB} /$ month & 4 Month \\
\hline 2 & $\begin{array}{c}\text { Internet Data Quota Package for } \\
\text { Elementary and Secondary } \\
\text { Education Students }\end{array}$ & $\begin{array}{l}35 \mathrm{~GB} / \\
\text { month }\end{array}$ & $5 \mathrm{~GB} /$ month & $30 \mathrm{~GB} /$ month & 4 Month \\
\hline 3 & $\begin{array}{l}\text { Internet Data Quota Package for } \\
\text { Educators at PAUD and Primary } \\
\text { and Secondary Education Levels }\end{array}$ & $\begin{array}{l}42 \mathrm{~GB} / \\
\text { month }\end{array}$ & $5 \mathrm{~GB} /$ month & $37 \mathrm{~GB} /$ month & 4 Month \\
\hline 4 & $\begin{array}{l}\text { Internet Data Quota Package for } \\
\text { Students and Lecturers }\end{array}$ & $\begin{array}{l}50 \mathrm{~GB} / \\
\text { month }\end{array}$ & $5 \mathrm{~GB} /$ month & $45 \mathrm{~GB} /$ month & 4 Month \\
\hline
\end{tabular}

Source: Secretary-General Regulation Number 14 of 2020 concerning Technical Guidelines for

Internet Data Quota Subsidy in 2020

From these data shows that the amount of subsidized internet quota adjusts to the needs at each level of education, such as students in early childhood education (PAUD) and primary and secondary education, educators at early childhood education and primary and secondary education, students and lecturer. As in the description in table 1, it can be seen that based on the description of the quota subsidy recipients, if seen from the volume and the distribution of volume between one another, there are differences. For example, for PAUD students, the amount is 20GB for one month with the distribution of 5GB for the general quota and 15GB for the study quota, while for primary and secondary school students, 35GB is given with the distribution of 5GB general quota and 30GB study quota. Furthermore, for PAUD, elementary, and secondary school educators, they are given $42 \mathrm{~GB}$ with the distribution of $5 \mathrm{~GB}$ general quota and 37GB study quota. Finally, students and lecturers are given 50GB with the distribution of 5GB general quota and 45GB study quota. Although there are differences in 
the proportion of the number of quotas given to all the target quota subsidies policy, the quota subsidies are given for the same duration, starting from September to December. Furthermore, concerning the subsidy recipients and their requirements can be seen in the following chart:

\section{Chart 1.}

\section{Requirements for Internet Data Quota Subsidy Recipients}

\begin{tabular}{|c|c|c|}
\hline $\begin{array}{l}\text { Subsidy Recipient } \\
\text { 1.Students in Early Childhood } \\
\text { Education (PAUD) and } \\
\text { Primary and Secondary } \\
\text { Education; } \\
\text { 2. Educators/ Teachers at PAUD } \\
\text { and Elementary and } \\
\text { Secondary Education Levels; } \\
\text { 3. College student; } \\
\text { 4. Lecturer. }\end{array}$ & Must fulfill & $\begin{array}{l}\text { Recipient Requirements } \\
\text { 1. Students at PAUD and Primary and } \\
\text { Secondary Education Levels } \\
\text { a. Registered in the Dapodik application; and } \\
\text { b. Have an active cell phone number in the } \\
\text { name of students/parents/family } \\
\text { members/guardians. } \\
\text { 2. Educators/Teachers at PAUD and Primary } \\
\text { and Secondary Education Level } \\
\text { a. Registered in the Dapodik application and } \\
\text { have an active status; and } \\
\text { b. Have an active cell phone number. } \\
\text { 3. Students } \\
\text { a. Registered in the PDDikti application, has an } \\
\text { active status in lectures or is currently in a } \\
\text { double degree; } \\
\text { b. Have a Study Plan Card in the current } \\
\text { semester; and c. Have an active cell phone } \\
\text { number. } \\
\text { 4. Lecturer } \\
\text { a. Registered on the PDDikti application and } \\
\text { has an active status in the 2020/2021 school } \\
\text { year; } \\
\text { b. Have a registration number (NIDN, NIDK, } \\
\text { or NUP); and c. Have an active cell phone } \\
\text { number. }\end{array}$ \\
\hline
\end{tabular}

Source: Secretary-General Regulation Number 14 of 2020 concerning Technical Guidelines for Internet Data Quota Subsidy in 2020

Based on this chart, it shows that the internet quota subsidy policy is designed with a specific target audience. These requirements indicate that this policy is planned by following its main objective to support online learning. 


\section{Policy Implementation Structure}

Implementation is an important stage of the decision-making process. This means that in the enforcement process, various stakeholders, organizations, procedures and technologies work together to implement policies to achieve policy goals (Stewart et al., 2008) in Khan, 2016). Including procedures related to programs, the interdependence of tasks, resources, etc. (Vancoppenolle et al, 2015). Implementation structure is an important factor in understanding why certain policy changes are successful and why other changes are unsuccessful (Blomgren, 2012). Policy implementation is a step that must be taken and carefully considered. Because the existence of not implementing policies means wasting resources, time and expertise to formulate policies and undermining the leadership position (Mugambwa et al, 2018).

In connection with the implementation structure of this program. The mechanism for providing internet quota subsidies is also published through the Pocket Book of the Study Quota Program for Students, Teachers, Students and Lecturers published by Education and Culture Ministry of the Republic of Indonesia which also contains the Secretary-General Regulation Number 14 of 2020 concerning Technical Guidelines for Internet Data Quota Subsidy in 2020 There are several stages of the implementation of this policy which include;

1. Mechanism of Initial Data Preparation, Verification, and Validation of Mobile Number Data At this stage

2. Internet Data Quota Subsidy Distribution Mechanism

3. Monitoring, Evaluation, and Reporting

Furthermore, related to the internet quota subsidy service mechanism can be seen in the following figure. 


\section{Figure 2.}

The mechanism for distributing subsidized internet data quota subsidy

The Commitment Making Officer (PPK) at the Center for Data and Information Technology determines the number of recipients of internet data quota subsidy according to the SPTJM.

The Center for Data and Information Technology (PDTI) sends a list of recipients of internet data quota subsidy to mobile operators

Cellular operators send internet data quotas according to the list of recipients of internet data quota subsidy from the Center for Data and Information Technology.

Cellular operators report the results of sending internet data quotas to the Commitment Making Officer (PPK) at the Data and Information Technology Center.

Internet data quota distribution is carried out for 4 (four) months from September to December 2020

Source: Secretary-General Regulation Number 14 of 2020 concerning Technical Guidelines for Internet

Data Quota Subsidy in 2020

Based on this figure, it can be seen that structurally, the mechanism for providing subsidy as an instrument for policy implementation has been structured accordingly. The Ministry of Education and Culture (Kemendikbud) has distributed internet data quota subsidy in the first and second phases this September by providing 27,305,495 cellphone numbers for educators and students throughout Indonesia. This figure has not reached half of the target recipient countries, and the total number of subsidy is around 59 million recipients, where the obstacle is because among them there are SPTJM data that do not meet the requirements (Larasati, 2020).

\section{The Behavior of Target Group}

From policy formulation to policy implementation, policy-makers must know the characteristics of their target group. This is done so that the policies implemented can be right on target. Regulatory ambiguity has an impact on non-compliance behavior, so the target group must understand these rules (Rachmawati, Rinjany, 2018). Meanwhile, Weaver (2009) states that a lack of resources can lead to mismatching behavior among target groups. Resources in this case can be in the form of capital obtained by target groups or services in the fields of education, health, etc.

Research results from the Indonesian Survey Flow (ASI, 2020) stated that as many as $78.9 \%$ of the public knew about the Ministry of Education and Culture's free internet subsidy program, while $20 \%$ said they did not know about the subsidy, while $1.1 \%$ claimed not to 
know/did not answer. The figure of $20 \%$ of the people who do not know this policy indicates that there are gaps in the provision of information, communication from the government to the public. The socialization provided to the community should also include the use of subsidized internet quotas appropriately for the benefit of learning. This is because ASI still discusses the findings that the general internet quota given to students is also used to access social media with a percentage of $38.3 \%$ and other games. Furthermore, looking at the resources side, the budget prepared by the government for this program is 7.2 trillion. However, at the time of writing, the program was running in the third month, so there was no report on budget use.

\section{Program Result}

The results of the policy program in this aspect relate to three important elements including output, outcome, impact. The output is a result of formal decision-making processes (Brand, 2013). This also defined as goods or product and services resulted from a development intervention; may also include changes related to the results achieved by the intervention (INTRAC, 2015). Outcomes are about approximately: the short-term and medium-term impact that the intervention output may or will achieve (INTRAC, 2015). Policy impact is the overall effect caused by a policy in real-life conditions (Dye, 1981) in Risal et al, 2013). The impact is about development interventions directly or indirectly, intentionally or unintentionally, positive and negative, primary and secondary long-term effects (INTRAC, 2015).

The three previous variables ranging from the policy design, implementation structure, and the behavior of the target group affect the outcome of this policy. Regulation of the Secretary-General Number 14 of 2020 concerning Technical Guidelines for Internet Data Quota Subsidy in 2020 is the result of policy output which is the answer to obstacles in the implementation of online learning, which at the time of writing this was entered in the third month of subsidies, the author as a student also received subsidies this. Meanwhile, regarding the outcome of this internet quota subsidy policy, we can see again in the previous survey (ASI, 2020) which stated that $85.6 \%$ of the public stated that this policy eased the economic burden on parents of students and students. Then, regarding whether the policy helps them with the learning process during the COVID-19 pandemic, as many as $82.9 \%$ of the public think that this policy helps the teaching and learning process. However, on the point of impact 
or long-term impact on this policy, of course, it cannot be assessed at this time. This is because the policies so far are still temporary, and the mechanism cannot be ascertained that they will continue, terminate, or change their mechanisms.

\section{Looking at The Good and Bad Reality}

The COVID-19 pandemic began infecting Indonesia in March 2020. The worldwide spread of COVID-19 has led to the closure of schools. According to the UNESCO report, more than 100 countries have closed their countries so that it has an impact on more than $50 \%$ (UNESCO, 2020). Various policies have been implemented by the Indonesian government to deal with the COVID-19 pandemic, such as PSBB and conducting Social Distancing. This policy resulted in several activities having to be carried out remotely or online to break the chain of the spread of the COVID-19 pandemic. The closure of schools as a result of the COVID-19 pandemic has led to a shift in learning to be online based (Abidah, Hidaayatullaah, Simamora, Fahabutar, \& Mutakinati, 2020; OwusuForfjour, Koomson, \& Hanson, 2020; Government of Indonesia, 2020; Zaharah \& Kirilova, 2020 ).

According to Dabbagh and Ritland (2005), online learning is an open and distributed learning system using pedagogical tools (educational aids), These are made possible through the Internet and web-based technologies, thereby facilitating the formation of learning and knowledge processes through meaningful actions and interactions. For example, what happens at various educational levels such as elementary school (SD), junior high school (SMP), high school (SMA), and Tertiary Education Institutions must do online or online distance learning which was initially only planned to be conducted for 2 weeks, but along with a significant increase in the number of infected cases, online distance learning is carried out until the semester ends and it may continue until the end of December 2020. In Indonesia, online learning is something new. Both students and educators are not prepared to carry out online learning (Maulipaksi, 2020). Online learning is the best solution in the world of education today during the COVID-19 pandemic (Hadi, 2020). Mastery of ICT is very important to support its implementation (UNESCO, 2020c). Based on the UNESCO report, $48 \%$ of students do not have mastery of ICT which can support online learning (UNESCO, 2020c). 
Based on the results of a national survey conducted by PT Arus Survey Indonesia, it shows that the Ministry of Education and Culture's Pusdatin Program related to free internet quota subsidy received a positive response from the public. The survey was conducted in 34 provinces in Indonesia with the number of respondents being 1,000 with a margin of error of $+/-3.10 \%$ at a $95 \%$ level of confidence. Where the survey was conducted via telesurveys, that is, respondents were interviewed by telephone using a questionnaire. The sample data validation was carried out by comparing the demographic characteristics of the sample obtained from the survey with the population obtained from the latest census data from the Central Statistics Agency (BPS). The survey results showed that as many as $84.7 \%$ of the public considered that the free internet development program was the right step in responding to the sense of crisis amid the corona outbreak (COVID-19), while $13.7 \%$ was not. The remaining $1.6 \%$ admitted that they did not know or did not answer. Meanwhile, as many as $85.6 \%$ of the public considered that the free internet subsidy program eased the economic burden on parents of students in buying internet packages, while $13.6 \%$ did not. The remaining $0.8 \%$ said they did not know or did not answer.

The implementation of online distance learning (PJJ) can be implemented more effectively if it is supported by adequate facilities, such as cellphones, laptops, or computers and the main support in implementing online long distance learning (PJJ) is the internet network, Wifi or pulse quota. However, this online distance learning (PJJ) system has both positive and negative impacts on various levels of society. The positive impact is that the implementation of online distance learning (PJJ) can help and contribute directly to the government's efforts to suppress and break the chain of the spread of COVID-19. Another good thing arising from this policy is for students to be more flexible and reduce accommodation and transportation expenses. Elementary, Junior High, and High School students also experienced a decrease in cost expenditures.

But looking at other realities, the conditions of the Covid-19 pandemic have resulted in extraordinary changes, including in the field of education. Especially in Indonesia, there is a lot of evidence that schooling greatly affects productivity and economic growth (Baharin, 2020). It is as if all levels of education are "forced" to transform to adapt suddenly drastically to learning from home through online media. It is not easy, because it is not fully prepared. The problem experienced by the world of education is that the learning process is not uniform, 
both the standards and the quality of the desired achievements (Atsani, 2020). The learning process in schools is the best public policy tool to increase knowledge and skills (Caroline, 1979).

According to Atsani (2020), distance learning during the coronavirus outbreak still encountered many obstacles in the field even though there was a ministerial circular so that the learning process from home was carried out online or online. Some students cannot participate in online or online learning because of the absence of an internet network signal. Besides, most of the parents who are in mediocre economic conditions also do not have smartphones or smartphones as media and online learning tools for their children. Some teachers are forced to innovate by directly distributing learning materials broadcast live on state-owned television to their students. The learning process that takes place from home inevitably requires direct supervision from parents. Even though at the same time, parents also have to divide their time to work, take care of the house, as well as help with children's learning. Distance learning constraints require a breakthrough because many regions experience limited technology, weak networks, and limited internet quotas. Besides, the curriculum and teaching content need a breakthrough because many regions experience limited technology, weak networks, and limited internet quotas. Besides, the curriculum and teaching content need to be formulated appropriately so that the education provided remains of high quality.

Based on this description, when compared with the advantages arising from the existence of this internet quota subsidy policy, the disadvantages are technological disparities and economic disparities which are still a problem in Indonesia. Not everyone has cellphones and laptops to support learning, and some areas in Indonesia still have no signal coverage. The internet network is not evenly distributed throughout the country (Arifa, 2020). When viewed from an access point of view, the challenge for the government is when the implementation of distance learning is implemented in areas where accessibility, infrastructure, and digital literacy are still low (Arifa, 2020). The results of the 2018 APJII National Internet User survey, show that more than half of internet users in Indonesia are Java (55.7\%), then Sumatra (21.6\%), then Sulawesi-Maluku Papua (10.9\%). \%)), Kalimantan (6.6\%), and Bali and Nusa Tenggara 5.2\% (gratis.kompas.id, March 30, 2020). One of the schools that 
is connected in the learning process from home is the limitation of the internet, both from network limits and quotas to access online learning (Arifa, 2020).

Another obstacle faced by the elementary school (SD) students is that many parents who can accompany their children in learning while elementary school (SD) students still need guidance in online learning, in addition to increasing spending has an impact on waste because it increases the number of monthly family expenses. Besides, technology support devices are currently priced quite expensive and not all levels of society can buy them. There are still many teachers in areas in Indonesia with alarming economic conditions. This limits teachers and students from enjoying the information technology facilities and infrastructure that are needed as a result of the COVID-19 pandemic. The lack of mentoring also has another impact, namely the number of students who use the internet quota that has been facilitated by parents to play games instead of studying (Aji, 2020). The role of parents is very important to support online learning (Đurišić \& Bunijevac, 2017; UNESCO, 2020b). The majority of the role of parents is in the form of supervision, parents motivate and help to continue to follow online learning (Hadi, 2020). Not a few parents have complained about this remote learning media (PJJ) via this online (internet). Especially for parents who work from home (WFH), they must still accompany their children, especially their children who are still at an early age. This is considering the uneven introduction of technology in the use of learning media, such as laptops, gadgets, and others (Miarso, 2004).

Another obstacle in implementing the internet quota subsidy policy is the condition of teachers in Indonesia who do not fully understand the use of technology. This can be seen from the large number of teachers born before the 1980s. This resulted in many limitations for them in using online media. Apart from teachers, students in several regions in Indonesia also have limited knowledge about the use of online media to support their learning activities. Students also feel complaints, even though they have been facilitated with quota subsidies, but there are many students' complaints in understanding the lecture material (Arifa, 2020). Based on a survey by the UGM Center for Innovation and Academic Studies of 3,353 students, they felt they understood the course material well, while the rest admitted they had little or very poor understanding (vice.com, 30 March 2010). One of the reasons for the lack of students' understanding of lecture material is the lack of readiness of lecturers in managing PJJ so that it affects learning outcomes. Learning online has been shown to be ineffective 
(Owusu-Fordjour et al, 2020). Students think that online learning and offline learning have differences. Students admit that they are not accustomed to studying without being accompanied by a teacher along with other students. Students have difficulty adapting because they have never carried out online learning at the previous education level (Maulipaksi, 2020). Several studies related to students' perceptions of offline and online learning show that students prefer learning offline (Anhusadar, 2020; Tratnik; Urh, \& Jereb, 2019). The quota subsidy policy provided by the Ministry of Education and Culture (Kemendikbud) for teachers and students during the corona virus pandemic is considered to have not solved school problems in the regions (republika.com, 2020). Schools still have to carry out the distance learning process (PJJ) amid the limitations of the internet network. Quota subsidy is considered useless when used in areas with hard-to-reach internet connections (republika.com, 2020). Because students still have to find a signal to a networkcovered place and get together. Furthermore, It also happened on 3T areas that have very minimal internet network (Qusthalani, 2019). This shows that there is an inequality of policy targets.

From various descriptions of the constraints and deficiencies in implementing the quota subsidy policy for educators and students as described above, it is broadly known that the main obstacle in implementing the policy is related to the readiness of human resources, lack of clarity in the direction of the local government, the absence of a proper curriculum that has been adapted to the conditions of the COVID-19 pandemic, and limited infrastructure, especially technology support and internet networks. The readiness of human resources including teachers and lecturers, students and support from parents is the most important part of implementing the internet quota subsidy policy. This is relevant to Riswandi's statement (republika.com, 2020), which states that the main problem for schools in the regions is not the lack of internet quota to study online. Moreover, students in local schools do not have devices, technology, or infrastructure for online distance learning (PJJ), such as smartphones or laptops. In rural areas it is found that many students do not have Android cellphones, let alone laptops. So that it hinders the implementation of learning by implementing online material (Atsani, 2020). 


\section{Conclusion}

\section{Summary}

The government's response to changes in community activities is very important to pay attention to concerning its policy choices. In the education sector, especially, where the change in the learning system to online learning also raises various reactions and new problems, especially in countries that are not ready to face technological changes. In Indonesia, the implementation of online learning also creates new problems, namely the increasing household internet consumption. So that the government took swift steps by providing internet quota subsidies. This policy is considered quite capable in terms of a systematic policy design, an integrated implementation structure, but in the behavior of the target, there are a few gaps, which are due to the lack of massive socialization. Meanwhile, the program results show that in terms of output and outcome, this policy has had a sufficiently positive impact on the recipients. Even though it is at the impact level, it cannot be assessed because of the ongoing policies.

Furthermore, further analysis is carried out by looking at the reality of policies in the field. Where the internet quota subsidy policy, according to a survey by Arus Survey Indonesia, has had a positive effect on meeting the objectives of the policy, namely supporting the implementation of online learning. However, on the other hand, several obstacles arise. One of them is a fundamental problem that has not yet received attention, regarding the inequality of infrastructure development, specifically in the support network for internet services which is a tool in the implementation of online learning.

\section{Suggestion}

This research is structured as an illustration amid the ongoing implementation of the internet quota subsidy policy. The journal article was written using the literature review method but did not research directly on the subject under study. Therefore, the limitation of this article is that when facing the actual situation in this field, our views as writers are limited, and in another way, the publication sources are still limited. Besides, because this study examines broadly based on previous research, and is not specific to any of the targets or loci. So that in the future, more comprehensive research with a more comprehensive or detailed conceptual framework with direct data collection is needed. It also includes specific locus and target specifications. 


\section{References}

\section{Books}

Caroline Hodges Persell. (1979). Educations and Inequality, The Roots and Results of Strattification in America's Schools, United States of America: The Free Press.

Miarso, Y. (2004). Menyemai Benih Teknologi Pendidikan, Jakarta: Rajawali.

\section{Book chapter}

Pulzl, Helga, Oliver Treib. (2017). Implementing public policy. Chapter 7 : Handbook of Public Policy Analysis: Theory, Politics, and Methods. Boca Raton : CRC Press

\section{Journal article}

Aji, Rizqon Halal Syah. (2020). Dampak Covid-19 pada Pendidikan di Indonesia: Sekolah, Keterampilan, dan Proses Pembelajaran. Jurnal Sosial \& Budaya Syar-i FSH UIN Syarif Hidayatullah Jakarta. Vol. 7 No. 5

Ansell. C, Sørensen. E, Torfing. J. (2017). Improving policy implementation through collaborative policymaking. Policy $\mathcal{E}$ Politics.

Arifa, Fieka Nurul. (2020). Tantangan Pelaksanaan Kebijakan Belajar Dari Rumah Dalam Masa Darurat Covid-19. Kajian Singkat Terhadap Isu Aktual dan Strategis, Pusat penelitian Badan Keahlian DPR RI. Vol. XII, No. 7/I/Puslit/April/2020

Atsani, KH. Lalu Gede Muhammad Zainuddin. (2020). Transformasi Media pembelajaran Pada Masa Pandemi Covid-19. 2020. Al-Hikmah Jurnal Studi Islam. Vol. 1, No. 1.

Baharin, R., Halal, R., dll. (2020). Impact of Human Resource Investment on Labor Productivity in Indonesia, Iranian Journal of Management Studies, 13(1), hal. 139-164.

Brand, Ulrich. (2013). State, context and correspondence. Contours of a historical-materialist policy analysis. Österreichische Zeitschrift für Politikwissenschaft (ÖZP), 42. Jg. (2013) H. 4, $425-442$

Chéné, Odriozola, Javier; Díaz-Noci, Javier; Serrano-Tellería, Ana; Pérez-Arozamena, Rosa; Pérez-Altable, Laura; Linares-Lanzman, Juan; García-Carretero, Lucía; Calvo-Rubio, Luis-Mauricio; Torres-Mendoza, Manuel; Antón-Bravo, Adolfo (2020). “Inequality in times of pandemics: How online media are starting to treat the economic consequences of the coronavirus crisis". Profesional de la información, v. 29, n. 4, e290403. 
Dabbagh, N. and Ritland. B. B, Online Learning, Concepts, Strategies And Application. Ohio: Pearson, 2005), 78. Baca juga Mayer, R. E, Multi Media Learning Prinsip-Prinsip Dan Aplikasi. (Yogyakarta: Pustaka Pelajar, 2009), 67.

Đurišić, M., \& Bunijevac, M. (2017). Parental Involvement as a Important Factor for Successful Education TT - Vključevanje staršev kot pomemben dejavnik uspešnega izobraževanja. CEPS Journal: Center for Educational Policy Studies Journal.

Gandolfi, Alberto. Planning of school teaching during COVID-19. Physica D 415 (2020) 132753 Hadi, Lukman. (2020). Persepsi Mahasiswa Terhadap Pembelajaran Daring Di Masa Pandemi Covid-19. Jurnal Zarah, Vol. 8 No. 2 (2020), Halaman 56 - 61.

Homsy, George C., Zhilin Liu \& Mildred E. Warner . (2019). Multilevel Governance: Framing the Integration of Top-Down and Bottom-Up Policymaking. International Journal of Public Administration.

Khan, Anisur Rahman. (2016).Policy Implementation: Some Aspects And Issues. Journal of Community Positive Practices, XVI(3) 2016, 3-12 ISSN Print: 1582-8344; Electronic: 22476571

Koontz, T. M. (2014). From Planning to Implementation: Top-Down and Bottom-Up Approaches for Collaborative Watershed Management. The Policy Studies Journal.

Korkmaz, Güneş, Çetin Toraman .Are We Ready for the Post-COVID-19 Educational Practice? An Investigation into What Educators Think as to Online Learning. International Journal of Technology in Education and Science (IJTES)Volume 4, Issue 4, Fall 2020 ISSN: 2651-5369 Lily, Abdulrahman Essa Al , Abdelrahim Fathy Ismail, Fathi Mohammed Abunasser, Rafdan Hassan Alhajhoj Alqahtani. 2020. Distance education as a response to pandemics: Coronavirus and Arab culture.Technology in Society 63 (2020) 101317

Mbunge, Elliot (2020). Effects of COVID-19 in South African health system and society: An explanatory study. Diabetes \& Metabolic Syndrome: Clinical Research \& Reviews 14 (2020) 1809e1814

Md Shah, Ain Umaira, Syafiqah Nur Azrie Safri, Rathedevi Thevadas, Nor Kamariah Noordin , Azmawani Abd Rahman , Zamberi Sekawi, Aini Ideris , Mohamed Thariq Hameed SultanInternational. COVID-19 outbreak in Malaysia: Actions taken by the Malaysian government. Journal of Infectious Diseases 97 (2020) 108-116 
Mugambwa, Joshua, Nkote Nabeta, Nichodemus Rudaheranwa, Will Kaberuka, John C. Munene. (2018). Policy Implementation: Conceptual Foundations, Accumulated Wisdom and New Directions. Journal of Public Administration and Governance ISSN 21617104 2018, Vol. 8, No. 3

Nicola, Maria, Zaid Alsafi , Catrin Sohrabi, Ahmed Kerwan, Ahmed Al-Jabir , Christos Iosifidis, Maliha Agha , Riaz Agha. The socio-economic implications of the coronavirus pandemic (COVID-19): A review. International Journal of Surgery 78 (2020) 185-193

Qusthalani. (2019). OMMEN as a Solution for 3T-area Physical Learning in Welcoming Education 4.0 and Education Even-distribution in Indonesia. Jurnal Teknodik Vol. 23 No. 2, Desember 2019

Risal, Semuel, DB. Paranoan, Suarta Djaja. (2013). Analisis Dampak Kebijakan Pertambangan Terhadap Kehidupan Sosial Ekonomi Masyarakat di Kelurahan Makroman. Jurnal Administrative Reform, Vol.1 No.3,Tahun 2013

Taylor, Heather Getha, M. J. (2018). Collaborating in the Absence of Trust? What Collaborative Governance theory and Practice Can Learn from the Literatures of Conflict Resolution, Psychology, and Law. American Review of Public Administration, 51-64.

Weaver. R. Kent (2009) Target Compliance: The Final Frontier of Policy Implementation. Issues in Governance Studies, Number 27. September 2009

\section{Journal article with DOI}

Abidah, A., Hidaayatullaah, H. N., Simamora, R. M., Fehabutar, D., \& Mutakinati, L. (2020). The Impact of Covid-19 to Indonesian Education and Its Relation to the Philosophy of "Merdeka Belajar." Studies in Philosophy of Science and Education. https://doi.org/10.46627/sipose.v1i1.9

Anhusadar, L. O. (2020). Persepsi Mahasiswa PAUD terhadap Kuliah Online di Masa Pandemi Covid 19. Journal of Islamic Early Childhood Education, 3(1), 44-58. https://doi.org/http://dx.doi.org/10.24014/k jiece.v3i1.9609

Blomgren, Roger.(2012).Autonomy or democratic cultural policy: that is the question, International Journal of Cultural Policy, 18:5, 519-529, DOI: 10.1080/10286632.2012.708861 
Capano, Giliberto \& Michael Howlett. (2019). Causal logics and mechanisms in policy design: How and why adopting a mechanistic perspective can improve policy design. Public Policy and Administration 0(0) 1-22. DOI: 10.1177/0952076719827068

Carter, David P and Christopher M Weible. Saba N Siddiki. Xavier Basurto. Integrating core concepts from the institutional analysis and development framework for the systematic analysis of policy designs: An illustration from the US National Organic Program regulation. Journal of Theoretical Politics 2016, Vol. 28(1) 159-185. DOI: $10.1177 / 0951629815603494$

Crawford, Joseph. Kerryn Butler-Henderson, Jürgen Rudolph, Bashar Malkawi, Matt Glowat, Rob Burton, Paola A. Magni, Sophia Lam.COVID-19: 20 countries' higher education intra-period digital pedagogy responses .Journal of Applied Learning \& Teaching Vol.3 No.1 (2020). DOI: https://doi.org/10.37. 074/jalt.2020.3.1.7

Dhawan, Shivangi (2020). Online Learning: A Panacea in the Time of COVID-19 Crisis. Journal of Educational Technology Systems 2020, Vol. 49(1) 5-22. DOI: 10.1177/0047239520934018

Owusu-Fordjour, C., Koomson, C. K., \& \& Hanson, D. (2020). The impact of COVID19 on learning-the perspective of the Ghanaian student. European Journal of Education Studies. https://doi.org/10.5281/zenodo.3753586

ÖZER, Mahmut.Educational Policy Actions by the Ministry of National Education in the times of COVID-19. . Kastamonu Education Journal, 2020, Vol. 28, No:3, 1124-1129 doi: 10.24106/kefdergi.722280

Rachmawati, Tutik \& Dhia Kalila Rinjany. (2016). Pick Your Own Rubbish: An Analysis Of Target Group Compliance In Public Policy Implementation. Journal Of Government $\mathcal{E}$ Politics Vol. 7 No. 3 August 2016 Http://Dx.Doi.Org/10.18196/ Jgp.2016.0033 / 373-387

Rasmitadila, Rusi Rusmiati Aliyyah, Reza Rachmadtullah, Achmad Samsudi, Ernawulan Syaodih, Muhammad Nurtanto, Anna Riana Suryanti Tambunan. (2020) The Perceptions of Primary School Teachers of Online Learning during the COVID-19 Pandemic Period: A Case Study in Indonesia. Journal of Ethnic and Cultural Studies 2020, Vol. 7, No. 2, 90-109 http://dx.doi.org/10.29333/ejecs/388

Vancoppenolle, Diederik. Harald Sætren \& Peter Hupe. (2015). The Politics of Policy Design and Implementation: A Comparative Study of Two Belgian Service Voucher Programs, 
Journal of Comparative Policy Analysis: Research and Practice, 17:2, 157-173, DOI:10.1080/13876988.2015.1006831

Wolf, EEA (2019). Dismissing the "Vocal Minority": How Policy Conflict Escalates When Policymakers Label Resisting Citizens. Policy Studies Journal, Vol. 0, No. 0, 2019. doi: 10.1111/psj.12370

\section{Newspaper article on website}

Adjie, Bayu. (2020, August 30). Internet Quota Assistance Does Not Solve Problems in Regions Retrieved from https://republika.co.id/berita/qfviyg384/bantuan-kuota-internet-takselesaikan-masalah-di-daerah

Maulipaksi, D. (2020). Pembelajaran di Rumah Jangan Hanya Fokus pada Akademik, Ajarkan Anak Tematik tentang Covid-19. Retrieved June 30, 2020, Retrieved from https://www.kemdikbud.go.id/main/blog/2 020/03/pembelajaran-di-rumahjanganhanya-fokus-pada-akademik-ajarkan-anaktematik-tentang-covid19

\section{Document}

INTRAC (the International NGO Training and Research Centre). (2015). Outputs, Outcomes and Impact. England

Peraturan Sekretaris Jenderal Nomor 14 Tahun 2020, tentang Petunjuk Teknis Bantuan Kuota Data Internet Tahun 2020

PT. Arus Survei Indonesia. (2020). National Survey Findings: Public Perception of the Ministry of Education and Culture's 2020 Internet Quota Assistance Program. Retrieved from file://C:/Users/acer/Downloads/Final-Laporan-Surnas-Kuota-Internet-ArusSurvei-Indonesia_compressed\%20(1).pdf.

UNESCO. (2020a). COVID-19 Educational Disruption and Response. Retrieved March 24, 2020, from https://iite.unesco.org/news/covid-19- educational-disruption-and-response/

UNESCO. (2020b). Parental and community involvement in education. Retrieved July 14, 1BC, from https://learningportal.iiep.unesco.org/en/iss ue-briefs/improve-learning/learnersandsupport-structures/parental-andcommunity-involvement-in

UNESCO. (2020c). UNESCO survey highlights measures taken by countries to limit impact of COVID-19 school closures. Retrieved July 14, 2020, from https://en.unesco.org/news/unesco-surveyhighlights-measures-taken-countrieslimitimpact-covid-19-school-closures 